\title{
21. BRYOZOA FROM SITE 282 WEST OF TASMANIA
}

\author{
Robin E. Wass and J.J. Yoo, Department of Geology and Geophysics, University of Sydney, Australia
}

\begin{abstract}
More than 15,000 bryozoan fragments have been identified from 17 samples in the late Miocene and late Pleistocene sediments at Site 282, Leg 29, Deep Sea Drilling Project, off the west coast of Tasmania (lat $42^{\circ} 14.76^{\prime} \mathrm{S}$, long $143^{\circ} 29.18^{\prime} \mathrm{E}$ ). Bryozoa are referable to the Orders Cyclostomata and Cheilostomata and represent 79 species belonging to 48 genera. Both late Miocene and late Pleistocene assemblages are closely related to assemblages found in the Tertiary of southern Australia, and the Recent of the southern Australian continental shelf.
\end{abstract}

\section{INTRODUCTION}

Recent and Tertiary bryozoan faunas from southern Australia have been documented for more than a century. The dominant works have been by MacGillivray (1879, 1895), Maplestone (1898), Stach (1933), and Brown (1958). Brown's monograph (1952) on the New Zealand Tertiary Bryozoa, recorded genera and species from the Recent and Tertiary of southern Australia. While a great deal of work has been done, there are still a large number of studies which have to be completed before the bryozoan faunas are properly understood. Recently, Wass and Yoo (1973) completed stratigraphic lists for some species of Tertiary Bryozoa from southeastern Australia, supplementing the compilation of Cockbain (1971). The bryozoan fauna of Recent age on the southern Australian continental shelf is enormous and preliminary studies of the fauna are proceeding (Wass, 1973, in press). A comparison of the Tertiary fauna described by Brown (1958), and that presently being studied on the continental shelf reveals many similarities, and it may be that the Recent fauna is a relict fauna lingering on from the Tertiary.

A preliminary study of Bryozoa from Site 282 shows a marked change in species diversity between the late Micoene and late Pleistocene, as well as a marked increase in the percentages of catenicelliform and cellariiform zoaria above the unconformity (Table 1). This is related to two factors: (1) in both forms, connection between zooecia is by means of nodes, and hence on death, the zoaria break into many zooecial fragments and (2) a change in environmental conditions which may have occurred.

\section{LATE MIOCENE BRYOZOA OF SITE 282}

Bryozoan fragments of both species and genera are rare in the late Miocene sediments. Twenty-three species belonging to 12 genera are present and all of these species are found in the late Pleistocene sediments. The late Miocene sediments of Core 1 are referred on foraminiferal evidence to the Globorotalia miotumida miotumida Zone.
The bryozoan fauna is small relative to that found in the late Pleistocene sediments and relative to records of late Miocene Bryozoa from southeastern Australia. The late Miocene Bryozoa in the Tertiary of southeastern Australia are also greatly diminished when compared with the middle Miocene faunas. Few studies have been made of Pliocene bryozoa in southeastern Australia, but apparently bryozoans are fewer in number than in the late Miocene.

The fauna observed at Site 282 is composed almost entirely of four zoarial types-catenicelliform, cellariiform, adeoniform, and vinculariiform. All four are represented by erect, delicate colonies which seems to indicate quiet conditions. The catenicelliform and cellariiform zoaria, because their zooecia have nodose connections, can tolerate increased sedimentation. The paucity of specimens in the late Miocene fauna makes any deductions on environmental conditions tenuous but it appears that Sample 282-1-6, $23 \mathrm{~cm}$ was probably associated with increased sedimentation and shallower depth whereas the rest of the samples indicate quiet, non-agitated conditions in deeper water. A feature of all the samples is the absence of membraniporiform zoaria, which is probably caused by sediment being too fine grained for bryozoan encrustation.

The initial accumulation of the bryozoan fauna almost certainly took place at shallower depths than those at present for Site $282(4207 \mathrm{~m})$. The bryozoan fauna has been displaced from the continental shelf to a depth of 4200 meters.

\section{LATE PLEISTOCENE BRYOZOA FROM SITE 282}

The dominant fauna at Site 282 represents the late Pleistocene. Seventy-nine species belonging to 48 genera have been recorded from Cores 282-1 to 282-4. The sediments in this interval fall within the Globorotalia truncatulinoides Zone. The quantity of bryozoan specimens increased immediately above the unconformity with 39 species being found in Sample 282-1$4,127 \mathrm{~cm}$. This represents an increase from only 10 species in Sample 282-1-5, $39 \mathrm{~cm}$, immediately below the 
Late Pleistocene and Late Miocene Bryozoa from Site 282

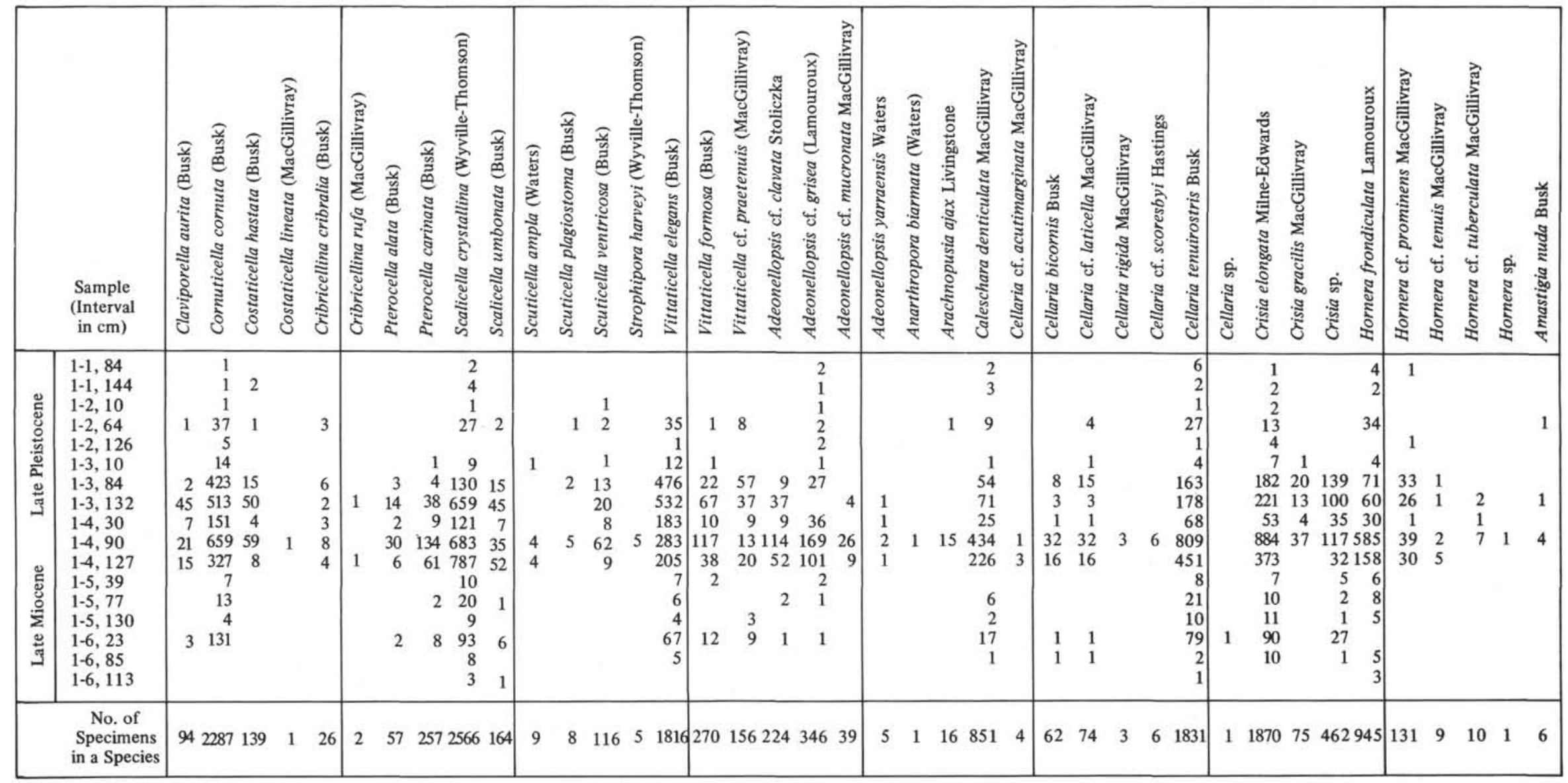


TABLE 1 - Continued

\begin{tabular}{|c|c|c|c|c|c|c|c|c|c|c|c|c|c|c|c|c|c|c|c|c|c|c|c|c|c|c|c|c|c|c|c|c|c|c|c|c|c|}
\hline & $\begin{array}{l}\text { Sample } \\
\text { (Interval } \\
\text { in } \mathrm{cm} \text { ) }\end{array}$ & 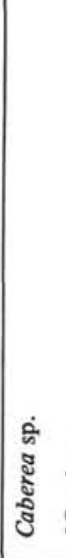 & $\begin{array}{l}\text { के } \\
\text { डूँ } \\
\text { डू }\end{array}$ & 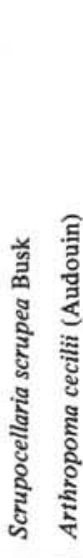 & 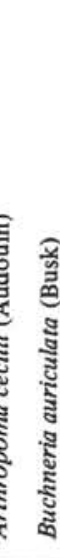 & 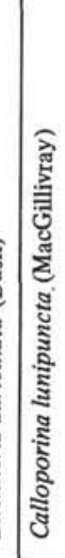 & 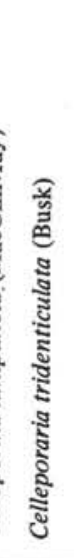 & 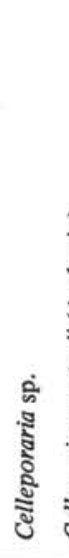 & 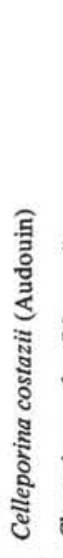 & 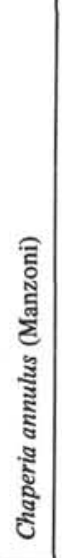 & 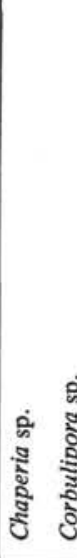 & 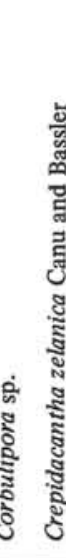 & 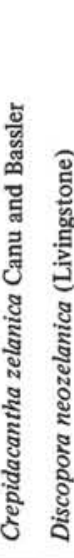 & 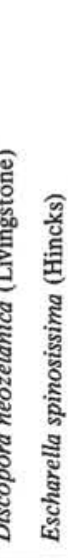 & 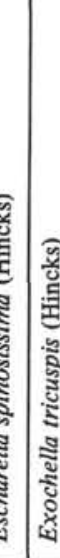 & 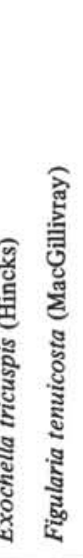 & 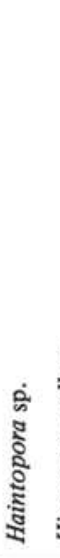 & : & 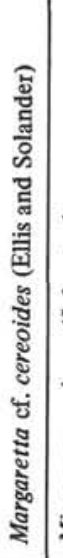 & 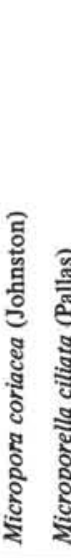 & 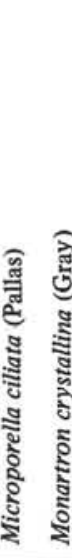 & 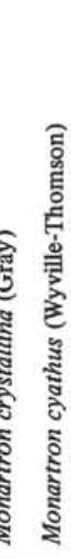 & 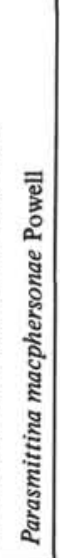 & 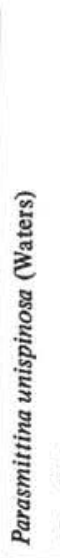 & के & 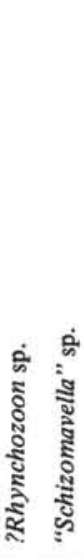 & 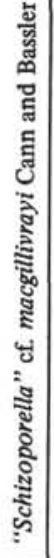 & 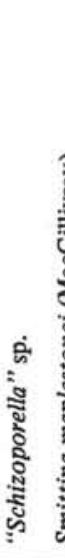 & 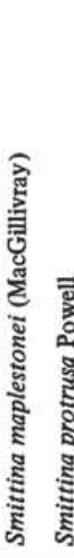 & 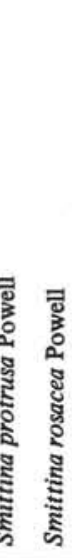 & 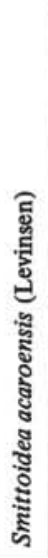 & 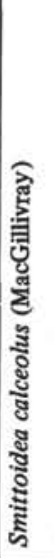 & 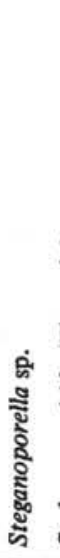 & 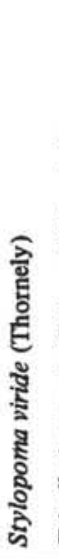 & 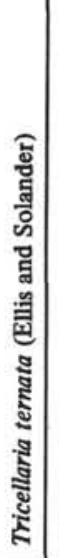 & 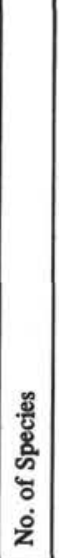 & 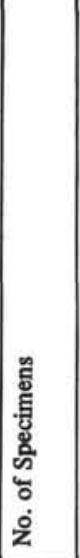 \\
\hline 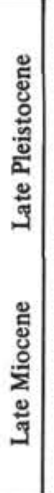 & $\begin{array}{l}1-1,84 \\
1-1,144 \\
1-2,10 \\
1-2,64 \\
1-2,126 \\
1-3,10 \\
1-3,84 \\
1-3,132 \\
1-4,30 \\
1-4,90 \\
1-4,127 \\
1-5,39 \\
1-5,77 \\
1-5,130 \\
1-6,23 \\
1-6,85 \\
1-6,113\end{array}$ & $\begin{array}{l}2 \\
5 \\
5\end{array}$ & 11 & $\begin{array}{r}6 \\
4 \\
2 \\
16 \\
8\end{array}$ & 1 & $\begin{array}{l}6 \\
4\end{array}$ & $\begin{array}{ll} & 1 \\
3 & 1 \\
6 & 2 \\
4 & \end{array}$ & 5 & 1 & 19 & $\begin{array}{l}2 \\
2\end{array}$ & 4 & 1 & 3 & 3 & $\begin{array}{ll}2 & 1 \\
& 1\end{array}$ & 1 & $\begin{array}{l}1 \\
1 \\
1\end{array}$ & 3 & $\begin{array}{r}1 \\
18 \\
3 \\
9 \\
10\end{array}$ & $\begin{array}{ll}7 & 2 \\
2 & \\
5 & 5 \\
2 & 4\end{array}$ & $\begin{array}{rr}8 & 2 \\
20 & 14 \\
6 & 1 \\
57 & 9 \\
46 & 4\end{array}$ & 1 & 5 & 1 & 1 & $\begin{array}{l}6 \\
1 \\
1\end{array}$ & 1 & $\begin{array}{ll}1 & 1\end{array}$ & $\begin{array}{r}3 \\
3 \\
1 \quad 100\end{array}$ & $\begin{array}{l}2 \\
2 \\
2\end{array}$ & 6 & 1 & 1 & \begin{tabular}{r|}
2 \\
17 \\
1 \\
17 \\
11 \\
\end{tabular} & $\begin{array}{r}8 \\
8 \\
6 \\
20 \\
6 \\
14 \\
36 \\
44 \\
36 \\
74 \\
39 \\
10 \\
12 \\
10 \\
22 \\
9 \\
4\end{array}$ & $\begin{array}{r}19 \\
17 \\
7 \\
7 \\
182 \\
14 \\
58 \\
1917 \\
2846 \\
806 \\
5735 \\
3106 \\
55 \\
92 \\
50 \\
563 \\
34 \\
8\end{array}$ \\
\hline & $\begin{array}{c}\text { No. of } \\
\text { Specimens } \\
\text { in a Species }\end{array}$ & 15 & 13 & 36 & 3 & 13 & 3 & 6 & 1 & 21 & 4 & 4 & 1 & 7 & 7 & 23 & 1 & 3 & 3 & 431 & 1614 & 4433 & 1 & 9 & 1 & 1 & 9 & 1 & 1 & 1106 & 6 & 8 & 1 & 1 & 48 & & 15,509 \\
\hline
\end{tabular}


unconformity. The maximum number of species (74) is found in Sample 282-14, $90 \mathrm{~cm}$. This cored interval also contains the maximum number of bryozoan fragments identified: Sample 282-1-4, $30 \mathrm{~cm}$ (36 species), Sample $282-1-3,132 \mathrm{~cm}$ (44 species), and Sample 282-1-3, $84 \mathrm{~cm}$ (36 species). Samples from higher in the cored interval show a sudden decline in species numbers: Sample 282$1-3,10 \mathrm{~cm}$ (14 species) and Sample 282-1-2, $126 \mathrm{~cm}$ (6 species). The number of fragments identified also decreases gradually from Sample 282-1-4, $90 \mathrm{~cm}$ to the top of the hole, except for a sudden decrease at Sample 282-1-4, $30 \mathrm{~cm}$, and an increase again at Sample 282-1-3, $132 \mathrm{~cm}$.

All the genera occurring in the late Pleistocene sediments have been recorded from the Recent of the southern Australian continental shelf. The position of Site 282 is between $138 \mathrm{~K}$ and $147 \mathrm{~K}$ of Wass et al. (1970). At the former locality, a bryozoan forest was noted, and at $147 \mathrm{~K}$, rippled sands, sponges, and Bryozoa were noted.

Species such as Scalicella crystallina are new to Australian waters, while species such as Scuticella ampla, Adeonellopsis obliqua, A. yarraensis. Crisia gracilis, Hornera prominens, $H$. tenuis, $H$. tuberculata, $H$. diffusa, and Figularia tenuicosta have not been recorded previously from the Pleistocene or Recent.

A number of the species, e.g., Anarthropora biarmata, Arachnopusia ajax, Caleschara denticulata, Celleporaria tridenticulata, Hornera frondiculata, Calloporina lunipuncta, Corbulipora sp., Escharella spinosissima, Micropora coriacea, Microporella ciliata, and Figularia tenuicosta are found in Recent samples at present being studied from the southern Australian continental shelf. Admittedly, the catenicellids, cellariids, and cyclostomes from this region have so far received scant attention.

For the late Pleistocene fauna as a whole, the dominant zoarial type is the catenicelliform, followed by the cellariiform, adeoniform, and vinculariiform. It would be reasonable to assume from this distribution that the fauna lived in slightly agitated waters with some sedimentation. The sedimentary particles, of course, would be too fine to allow encrustations of Bryozoa on them. However, it is highly unlikely that the bryozoans were at one stage living at the position of Site 282 , as such a species diversity and abundance of fauna would not be commensurate with a depth of 4200 meters. The bryozoan fauna could therefore have been derived from two slightly different environments, one associated with some agitation and sedimentation which would support the catenicelliform and cellariiform growth, and the second, sheltered somewhat from agitation and sedimentation in slightly deeper water. Studies of Bryozoa on the southern Australian continental shelf have shown that all four zoarial growth forms can be found living at one locality. The bushy catenicelliform and cellariiform zoaria possibly protect the more erect, rigid adeoniform and vinculariiform zoaria from agitation of the environment.

For the fauna found in the late Miocene and late Pleistocene, the species diversity is commensurate with the regression which took place in southern Australia during late Miocene time. This, associated with a reduction in temperature, diminished the fauna greatly from that found in the middle Miocene. The great increase in species in the late Pleistocene signifies an influx of bryozoan fauna into the region and probably relates to a Pleistocene transgression. There is no way for us to differentiate between a late Pleistocene and a Recent fauna and some of the fauna herein called late Pleistocene may, in fact, be Recent. It is interesting to note that many of the species identified, range back into the Tertiary giving credence to an idea expressed earlier in this report that the Recent bryozoan fauna of the southern Australian continental shelf is a relict fauna lingering from Tertiary time.

\section{CONCLUSIONS}

Bryozoa from late Pleistocene and late Miocene strata of Site 282 show definite affinities with Australian faunas from the same time. The late Miocene fauna is poorly represented compared to the late Pleistocene fauna and this is a result of decrease in temperature and a regression through the late Miocene. The late Pleistocene fauna, which may in fact be Recent, is very well developed, being represented by 79 species. This fauna may be associated with a transgression. In both faunas, the dominant zoarial types are catenicelliform, cellariiform, adeoniform, and vinculariiform. The distribution of these types seems to indicate a mixing of two environments; one of these would be agitated with sedimentation proceeding and it would support the catenicelliform and cellariiform types; the adeoniform and vinculariiform types would tend to be found in less agitated waters associated with little sedimentation and greater depths. Alternatively, the four types may be found in the same environment with the abundance of catenicelliform and cellariiform zoaria offering protection to the rigid and erect adeoniform and vinculariiform types. The faunas would have originally been located on the continental shelf and would have reached their present position by slumping.

\section{ACKNOWLEDGMENTS}

Our thanks go to Assoc. Professor G. H. Packham who made arrangements for us to study the material. Miss P. L. Cook has assisted in some identifications and Mr. D. J. Taylor has critically read the manuscript. All photographs were taken by the Scanning Electron Microscope Unit at the University of Sydney. The study has been supported by A.R.G.C. grant D72/15169 which enabled R. E. W. to make comparisons with bryozoan material in the National Museum of Victoria. Mr. T. A. Darragh arranged for the loan of material from that Institution. To all these people, we are grateful for their assistance.

\section{REFERENCES}

Brown, D. A., 1952. The Tertiary cheilostomatous Polyzoa of New Zealand: London (British Museum Natural History). 1958. Fossil cheilostomatous Polyzoa from southwest Victoria: Geol. Surv. Victoria, Mem. 20.

Cockbain, A. E., 1971. Tertiary cheilostomatous Bryozoa from Victoria: Roy. Soc. Victoria Proc., v. 84, p. 173-182. 
MacGillivray, P. H., 1879. Polyzoa. In McCoy, P. H., Prodromus of the Zoology of Victoria, v. III, p. 15-35. 1895. A Monograph of the Tertiary Polyzoa of Victoria: Roy. Soc. Victoria Trans., (n.s.), v. 4, p. 1-166. Maplestone, C. M., 1898. Further descriptions of the Tertiary Polyzoa of Victoria, I: Roy. Soc. Victoria Proc., v. 11, p. 14-22.

Stach, L. W., 1933. Victorian Tertiary Catenicellidae (Bryozoa), I: Roy. Soc. Victoria Proc., v. 45, p. 85-98.

Wass, R. E., 1973. Frontal wall calcification in a Recent cribrimorph genus from Australia. In Larwood, G. P., (Ed.),
Living and Fossil Bryozoa: Recent Advances in Research: London (Academic Press), p. 361-367.

in press. A revision of the bryozoan genus Corbulipora MacGillivray. Roy. Soc. Victoria Proc.

Wass, R. E., Conolly, J. R., and Macintyre, R. J., 1970. Bryozoan carbonate sand continuous along southern Australia: Marine Geol., v. 9, p. 63-73.

Wass, R. E. and Yoo, J. J., 1973. Stratigraphic ranges of some bryozoan species in the Tertiary of south-eastern Australia. Rept. Geol. Sci., Univ. Sydney, 1973/3, p. 1-13. 


\section{PLATE 1}

Figures 1-9, 11, 12, Sample 282-1-4, $90 \mathrm{~cm}$;

Figure 10, Sample 282-1-4, $127 \mathrm{~cm}$.

Figures 1, 2 Crisia elongata Milne-Edwards

SUP 17400-1.

1. Magnification $\times 30$.

2. Magnification $\times 35$.

Figure $3 \quad$ Crisia sp.

Magnification $\times 60$; SUP 17402 .

Figures 4, $5 \quad$ Cellaria tenuirostris Busk

SUP 17403-4.

4. Magnification $\times 45$.

5. Magnification $\times 35$.

Figure $6 \quad$ Cellaria bicornis Busk

Magnification $\times 45$; SUP 174054-5.

Figure $7 \quad$ Hornera cf. tuberculata MacGillivray Magnification $\times 45$; SUP 17406.

Figures 8,11 Hornera frondiculata Lamouroux Magnification ×30; SUP 17407-8.

Figure $9 \quad$ Hornera cf. prominens MacGillivray Magnification $\times 60$; SUP 17409.

Figure $10 \quad$ Hornera sp.

Magnification $\times 45$; SUP 17410 .

Figure 12 Hornera cf. tenuis MacGillivray Magnification $\times 60$; SUP 17411 .

Figure 13 Cellaria cf. acutimarginata MacGillivray Magnification $\times 75$; SUP 17412 . 


\section{PLATE 1}
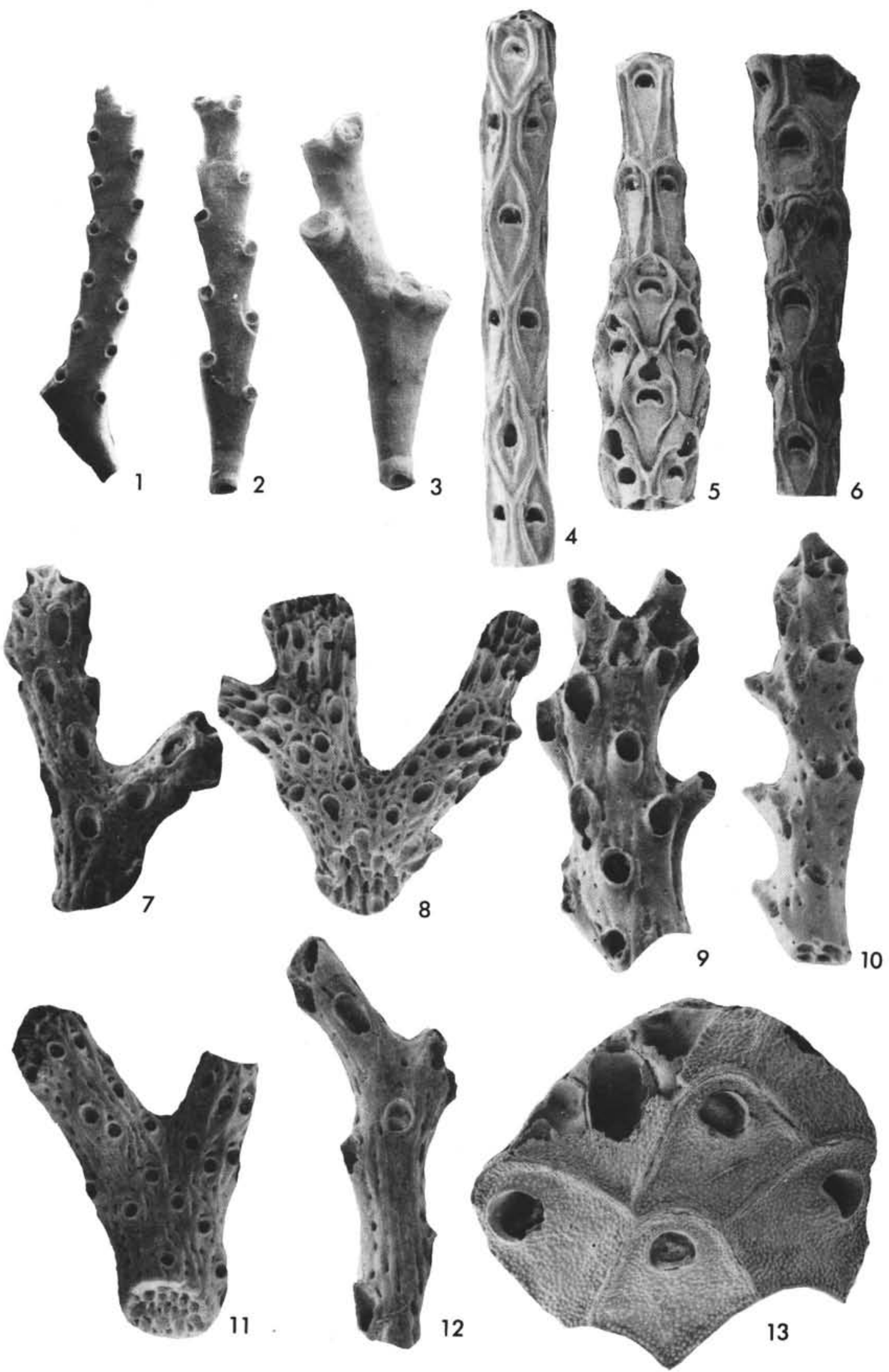


\section{PLATE 2}

Figures 1-3, 7, 8, Sample 282-1-4, $90 \mathrm{~cm}$; Figures 4, 5, 9-11 Sample 282-1-4,127 cm; Figure 6, Sample 282-1-4, $30 \mathrm{~cm}$.

Figure 1

Figure 2

Figure 3

Figure 4

Figure 5

Figure 6

Figures 7,8

Figure 9

Figure 10

Figure 11
Amastigia nuda Busk
Magnification $\times 60$; SUP 17413 .

Cellaria cf. laticella MacGillivray Magnification $\times 45$; SUP 17414 .

Cellaria cf. scoresbyi Hastings Magnification $\times 45$; SUP 17415 .

?Canda sp.

Magnification $\times 75$; SUP 17416 .

Caberea sp.

Magnification $\times 50$; SUP 17417 .

Scrupocellaria scrupea Busk Magnification X90; SUP 17418 .

Micropora coriacea (Johnston) SUP 17419-20.

7. Magnification $\times 90$.

8. Magnification $\times 45$.

Monartron crystallina (Gray)

Magnification $\times 110$; SUP 17421 .

Tricellaria ternata (Ellis and Solander) Magnification $\times 150$; SUP 17422 .

Monartron cyathus (Wyville-Thomson) Magnification $\times 150$; SUP 17423 . 


\section{PLATE 2}
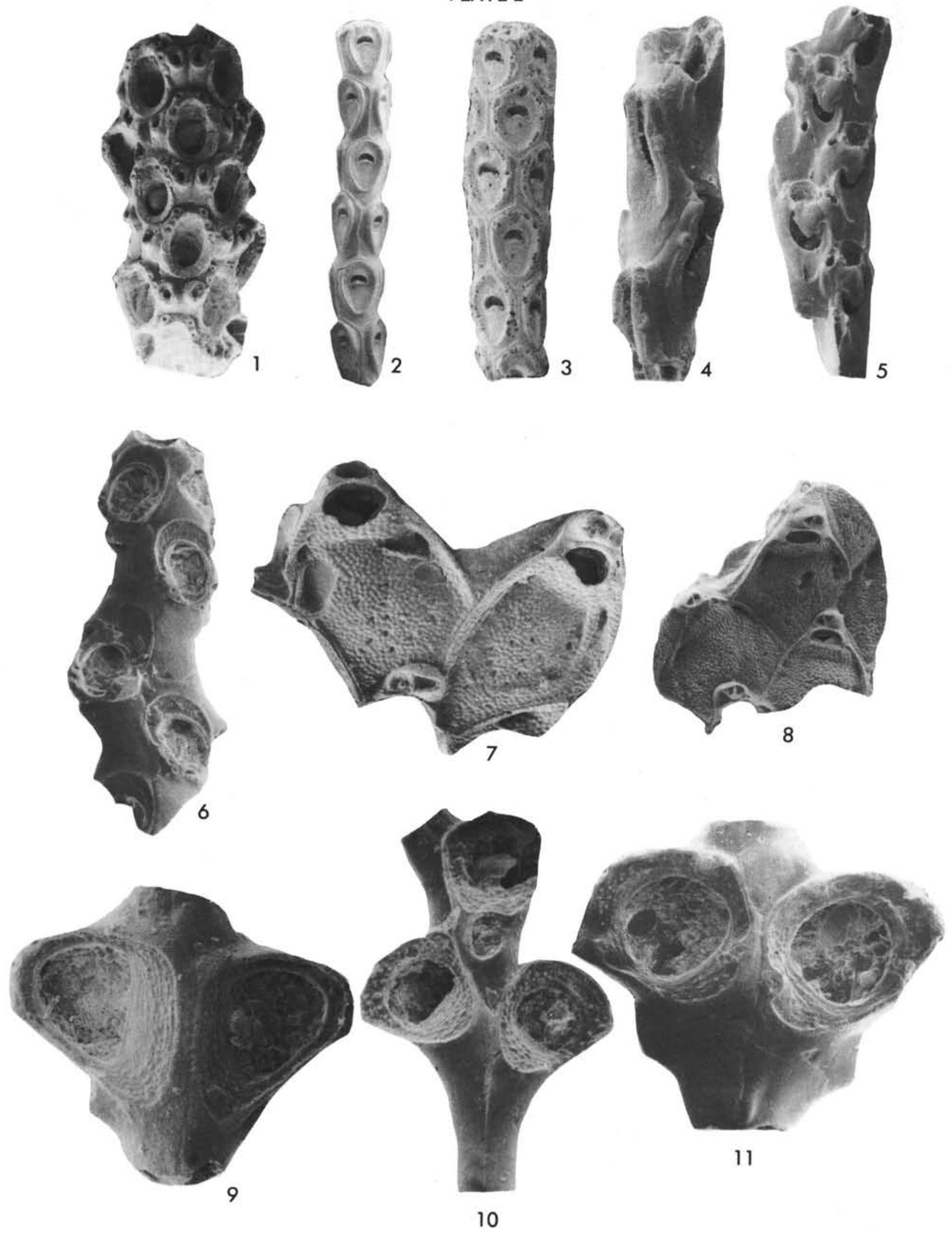


\section{PLATE 3}

All figures, Sample 282-1-4, $90 \mathrm{~cm}$.

Figure 1 Figularia tenuicosta (MacGillivray) Magnification $\times 75$; SUP 17424 .

Figure 2 Discopora neozelanica (Livingstone) Magnification $\times 50$; SUP 17425 .

Figure $3 \quad$ Steganoporella sp. Magnification $\times 35$; SUP 17426.

Figure $4 \quad$ Corbulipora sp.

Magnification $\times 90$; SUP 17427.

Figure $5 \quad$ Caleschara denticulata MacGillivray Magnification $\times 60$; SUP 17428.

Figure $6 \quad$ ?Parellisina $\mathrm{sp}$.

Magnification $\times 60$; SUP 17429 .

Figure $7 \quad$ Chaperia annulus (Manzoni) Magnification $\times 60$; SUP 17430 .

Figure $8 \quad$ Hiantopora sp.

Magnification $\times 75$; SUP 17431 .

Figure $9 \quad$ Chaperia sp.

Magnification $\times 50$; SUP 17432 .

Figure $10 \quad$ Arachnopusia ajax Livingstone Magnification $\times 60$; SUP 17433. 
PLATE 3
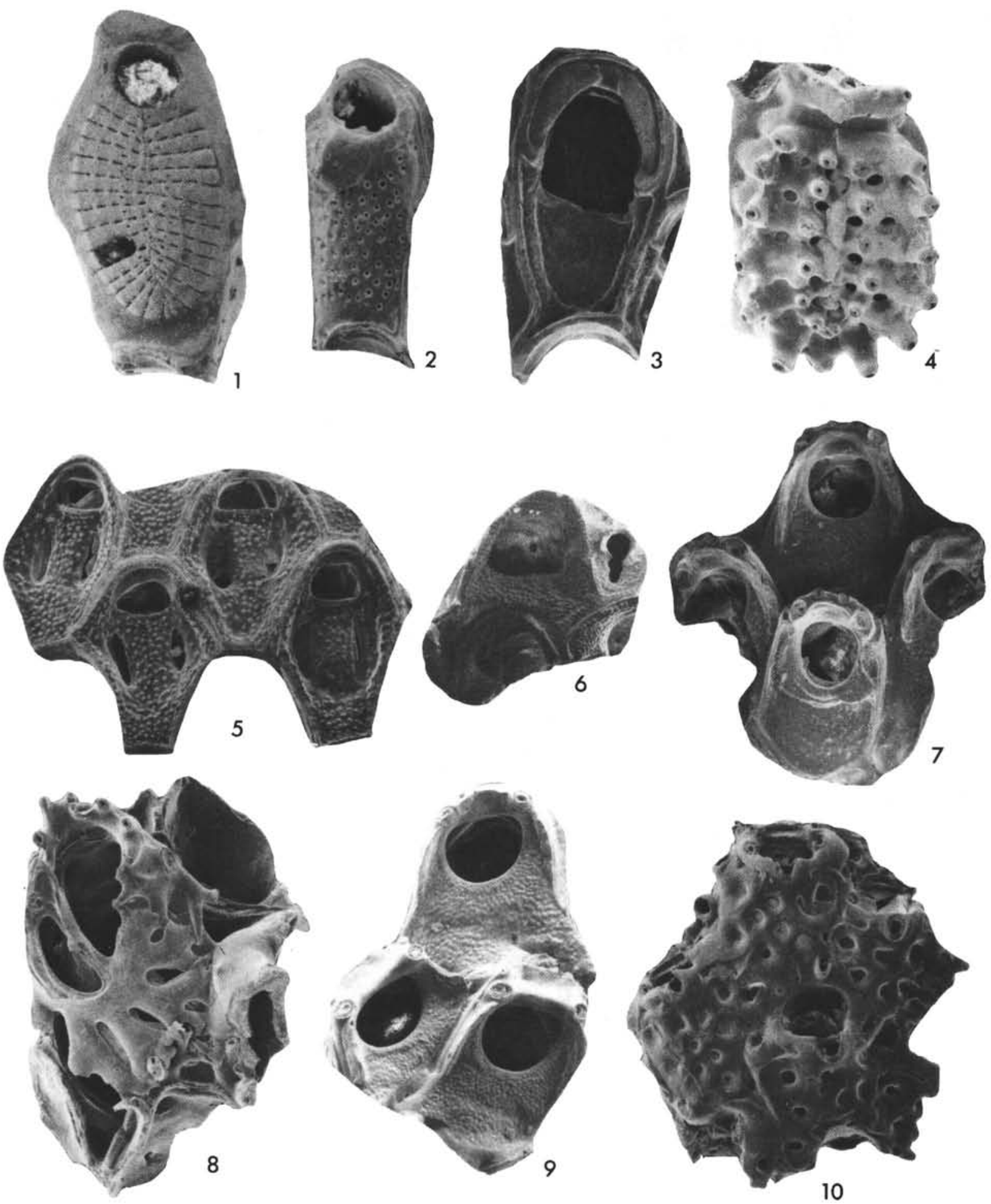


\section{PLATE 4}

All figures, Sample 282-1-4, $90 \mathrm{~cm}$.

Figures 1, 11

Vittaticella formosa (Busk)

SUP 17434-5.

1. Magnification $\times 90$.

11. Magnification $\times 75$.

Figures 2, $4 \quad$ Cornuticella cornuta (Busk)

Magnification $\times 90$; SUP 17436-7.

Figures 3, 8 Strophipora harveyi (Wyville-Thomson) SUP 17438-9.

3. Magnification $\times 30$.

8. Magnification $\times 90$.

Figure $5 \quad$ Scalicella umbonata (Busk)

Magnification $\times 110$; SUP 17440 .

Figures 6,9 Vittaticella elegans (Busk)

SUP 17441-2.

6. Magnification $\times 90$.

9. Magnification $\times 150$.

Figure $7 \quad$ Vittaticella $\mathrm{cf}$. praetenuis (MacGillivray) Magnification $\times 90$; SUP 17443.

Figure $10 \quad$ Scalicella crystallina (Wyville-Thomson) Magnification $\times 110$; SUP 17444. 
PLATE 4
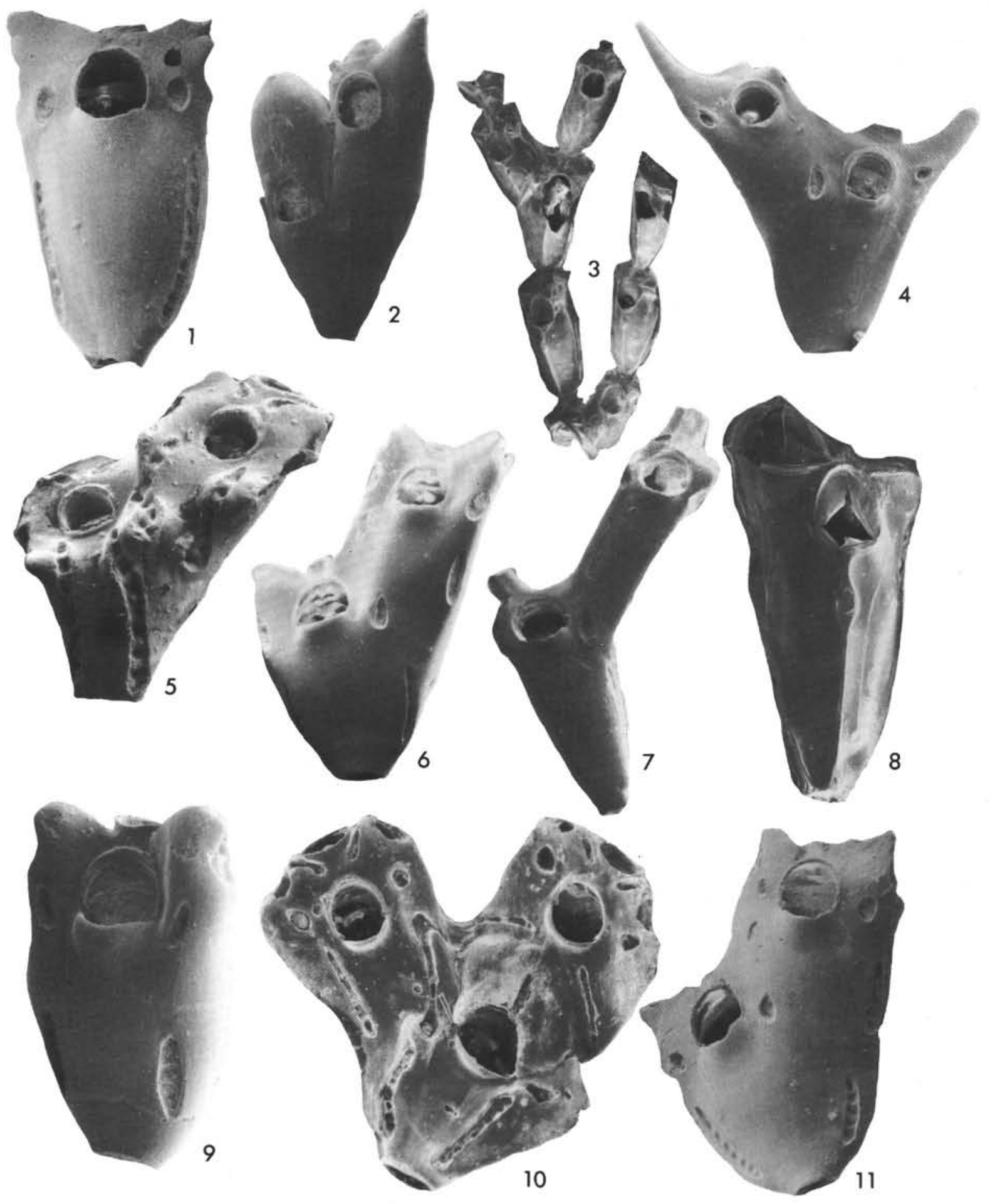


\section{PLATE 5}

Figure 1, Sample 282-1-3, $132 \mathrm{~cm}$;

Figures 2-10, Sample 282-1-4, $90 \mathrm{~cm}$.

Figure 1 Cribricellina rufa (MacGillivray)

Magnification $\times 110$; SUP 18439 .

Figure 2 Scalicella crystallina (Wyville-Thomson) Magnification $\times 90$; SUP 17445.

Figure $3 \quad$ Pterocella alata (Busk)

Magnification $\times 90$; SUP 17446.

Figure $4 \quad$ Scuticella plagiostoma (Busk)

Magnification $\times 90$; SUP 17447 .

Figures 5,6 Pterocella carinata (Busk)

Magnification $\times 90$; SUP 17448-9.

Figure $7 \quad$ Scuticella ampla (Waters)

Magnification $\times 110$; SUP 18400 .

Figure $8 \quad$ Cribricellina cribralia (Busk)

Magnification $\times 150$; SUP 18401 .

Figure 9 Claviporella aurita (Busk)

Magnification $\times 110$; SUP 18402 .

Figure 10 Scuticella ventricosa (Busk)

Magnification $\times 90$; SUP 18403 . 


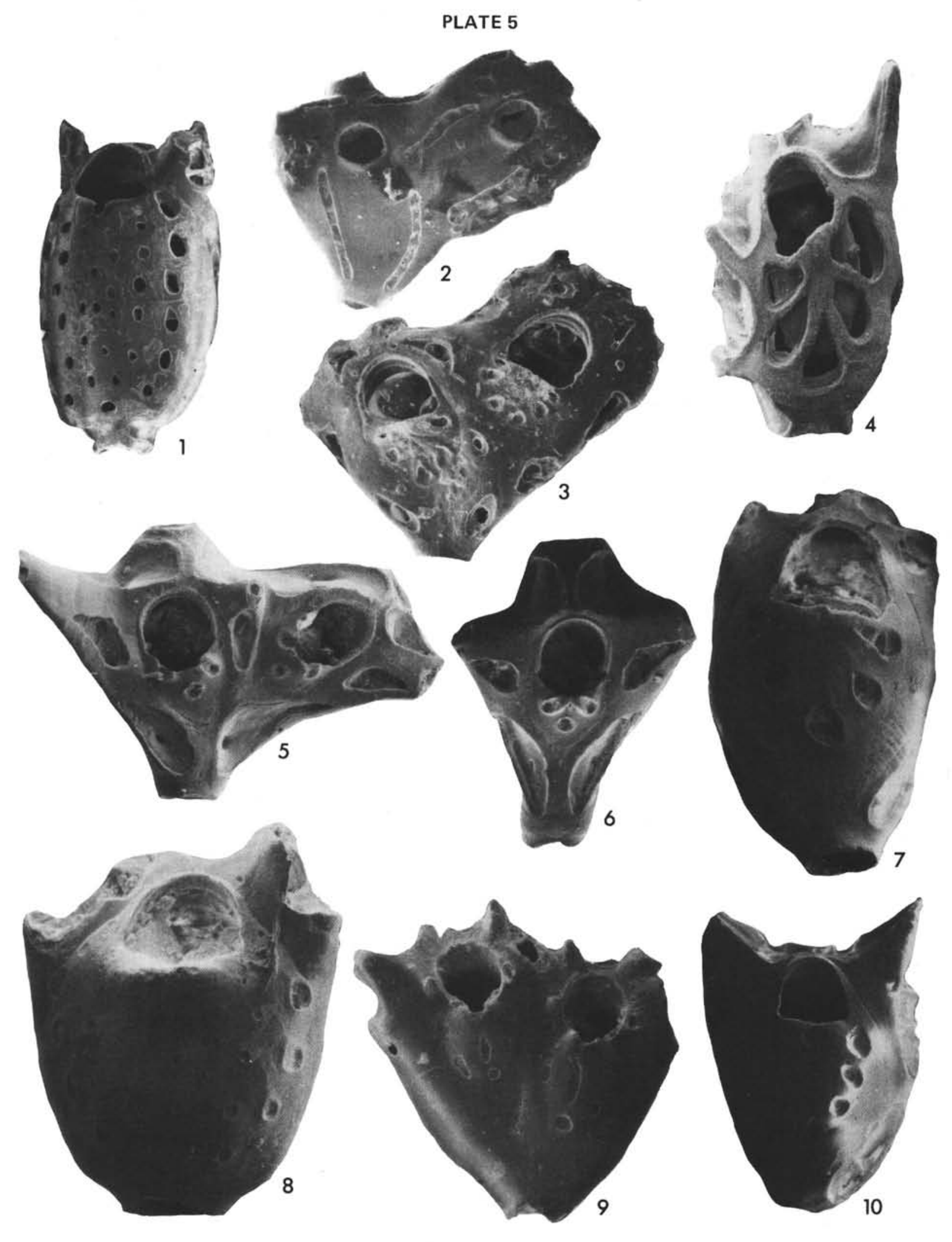


PLATE 6

All figures Sample 282-1-4, $90 \mathrm{~cm}$.

Figure $1 \quad$ Costaticella lineata (MacGillivray) Magnification $\times 90$; SUP 18404 .

Figures 2, 3, Costaticella hastata (Busk) 5,6 SUP 18405-8.

2,3. Magnification $\times 90$.

5. Magnification $\times 150$.

6. Magnification $\times 75$.

Figure $4 \quad$ Celleporina costazii (Audouin) Magnification $\times 90$; SUP 18409 .

Figure $7 \quad$ Stylopoma viride (Thornely) Magnification $\times 90$; SUP 18410 .

Figure $8 \quad$ Celleporaria tridenticulata (Busk) Magnification $\times 80$; SUP 18411 .

Figure 9 Arthropoma cecilii (Audouin) Magnification $\times 110$; SUP 18412. 
PLATE 6
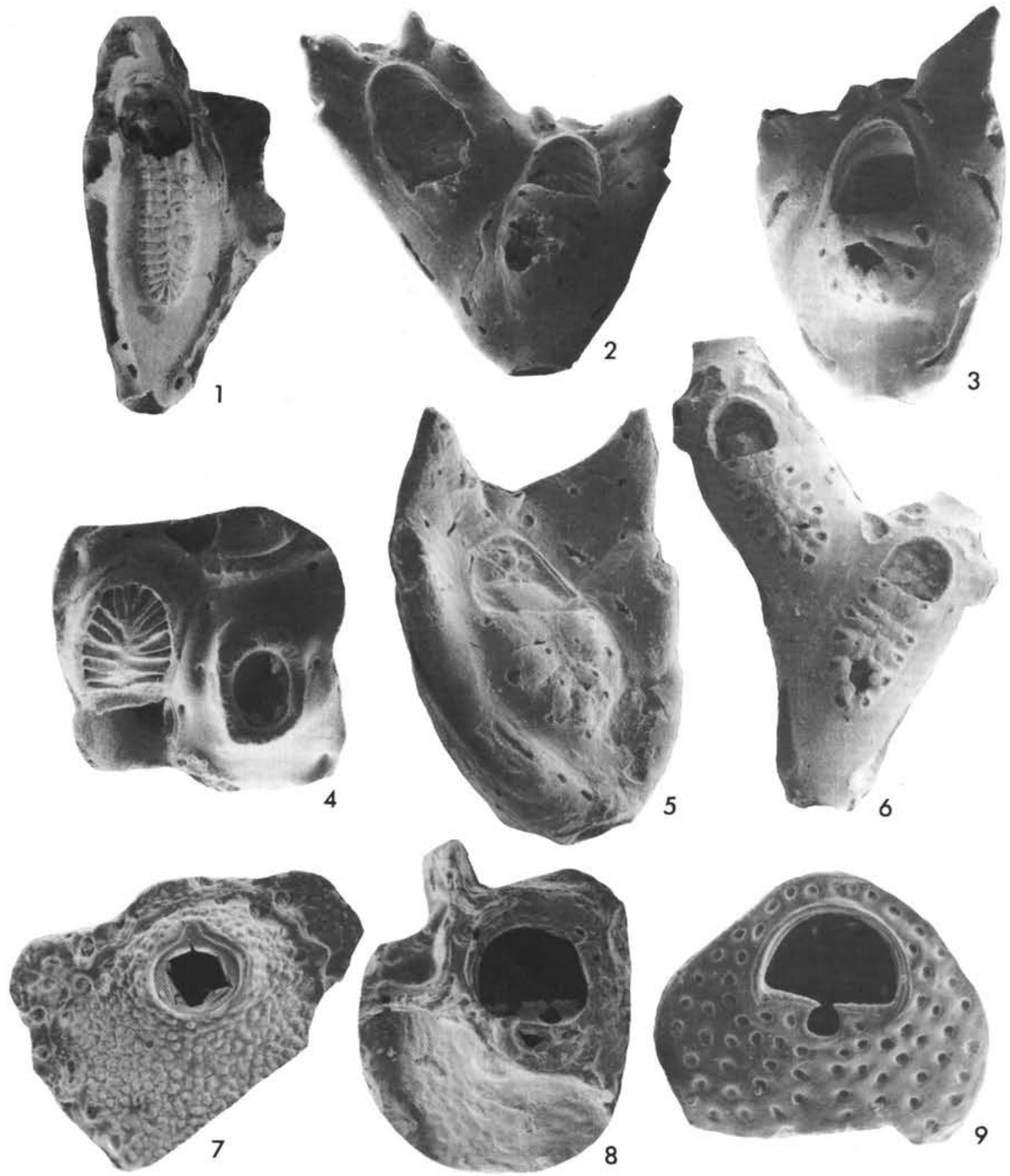


\section{PLATE 7}

Figures 1-3, 5, 7, 8, Sample 282-1-4, $90 \mathrm{~cm}$; Figure 4, Sample 282-1-3, $132 \mathrm{~cm}$; Figures 6, 9, Sample 282-1-4, $30 \mathrm{~cm}$.

Figure $1 \quad$ Crepidicantha zelanica Canu and Bassler Magnification $\times 150$; SUP 18413 .

Figure 2 Calloporina lunipuncta (MacGillivray) Magnification $\times 90$; SUP 18414 .

Figure $3 \quad$ Buchneria auriculata (Busk) Magnification $\times 45$; SUP 18415 .

Figure $4 \quad$ "Schizoporella" sp. Magnification $\times 120$; SUP 18416 .

Figure $5 \quad$ "Schizoporella" cf. macgillivayi Canu and Bassler Magnification $\times 75$; SUP 18417.

Figures 6,9 Exochella tricuspis (Hincks) Magnification $\times 150$; SUP $18418-9$.

Figure $7 \quad$ Microporella ciliata (Pallas) Magnification $\times 150$; SUP 18420 .

Figure $8 \quad$ Margaretta cf. cereoides (Ellis and Solander) Magnification $\times 60$; SUP 18421 . 
PLATE 7
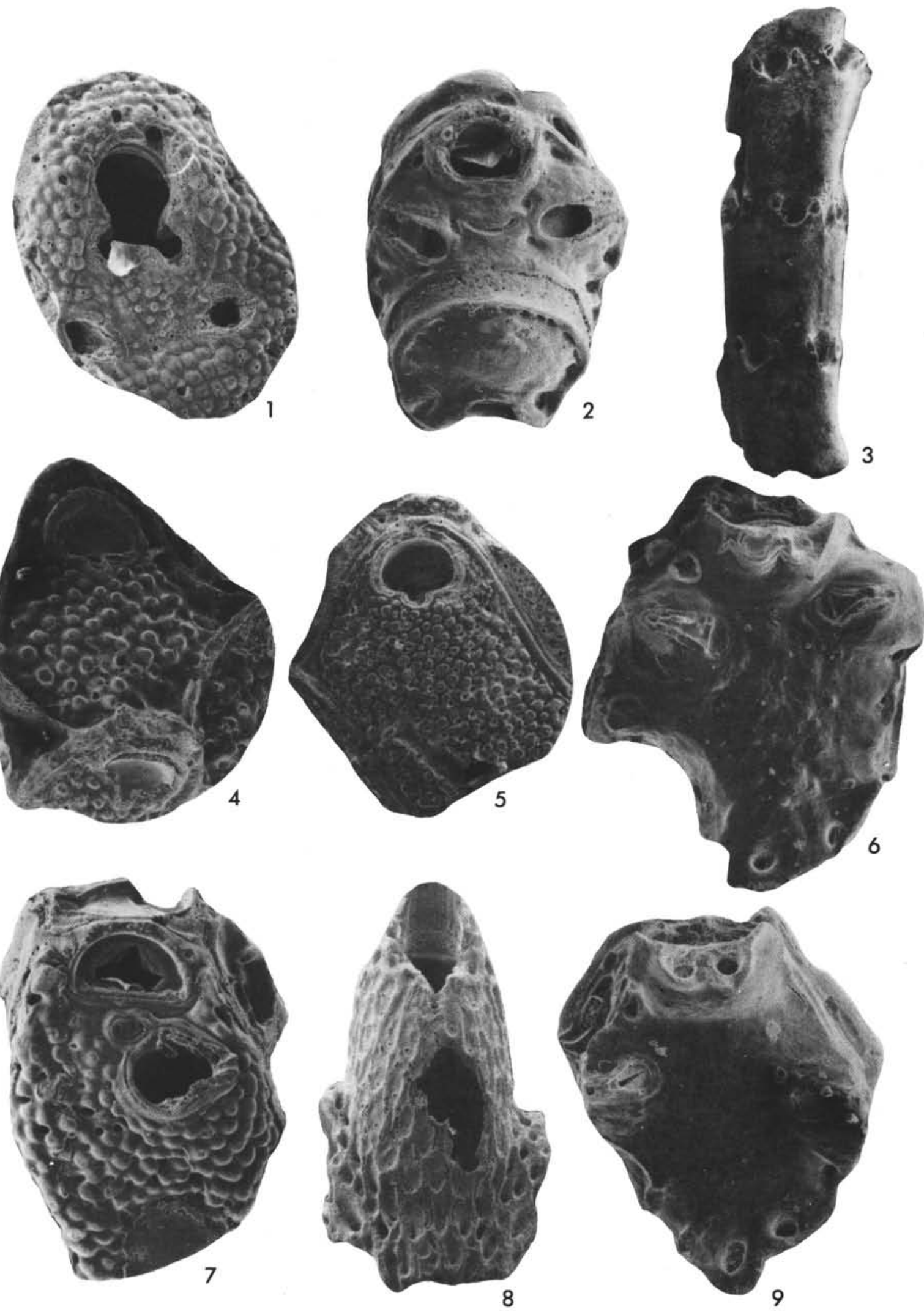


\section{PLATE 8}

Figures 1, 3-9, Sample 282-1-4, $90 \mathrm{~cm}$;

Figure 2, Sample 282-1-4, $127 \mathrm{~cm}$.

Figures 1, 2 Adeonellopsis cf. clavata Stoliczka SUP 18422-3.

1. Magnification $\times 110$.

2. Magnification $\times 90$.

Figure 3 Escharella spinosissima (Hincks) Magnification $\times 100$; SUP 18440 .

Figures 4, 8 Adeonellopsis cf. grisea (Lamouroux) Magnification $\times 75$; SUP 18424-5.

Figure 5 Anarthropora biarmata (Waters) Magnification $\times 75$; SUP 18426 .

Figure 6 Adeonellopsis cf. mucronata MacGillivray Magnification $\times 90$; SUP 18427.

Figure $7 \quad$ Adeonellopsis yarraensis Waters Magnification $\times 150$; SUP 18428.

Figure 9 ?Rhynchozoon $\mathrm{sp}$.

Magnification $\times 90$; SUP 18429. 


\section{PLATE 8}
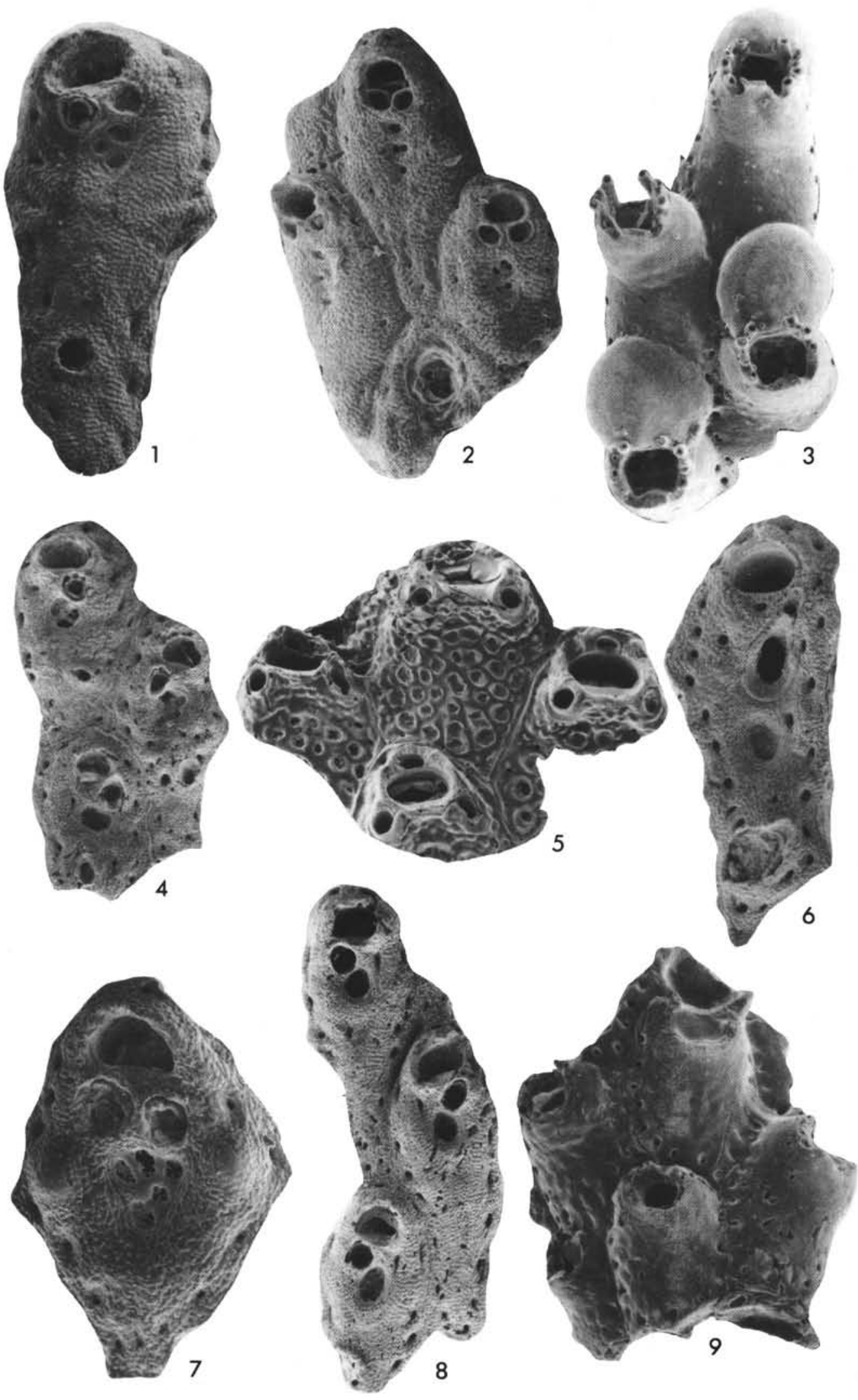


\section{PLATE 9}

Figure 1, Sample 282-1-3, $132 \mathrm{~cm}$;

Figures 2-9, Sample 282-1-4, $90 \mathrm{~cm}$.
Figures 1,9 Parasmittina unispinosa (Waters)
SUP 18430-1.
1. Magnification $\times 90$.
9. Magnification $\times 50$.

Figure 2 "Schizomavella" sp.

Magnification $\times 75$; SUP 18432 .

Figure $3 \quad$ Smittina rosacea Powell

Magnification $\times 60$; SUP 18433 .

Figure $4 \quad$ Smittoidea calceolus (MacGillivray) Magnification $\times 75$; SUP 18434.

Figure $5 \quad$ ?Parasmittina macphersonae Powell Magnification $\times 90$; SUP 18435.

Figure 6 ?Smittina maplestonei (MacGillivray) Magnification $\times 60$; SUP 18436 .

Figure $7 \quad$ Smittoidea acaroensis Levinsen Magnification $\times 30$; SUP 18437.

Figure $8 \quad$ Smittina protrusa Powell Magnification $\times 75$; SUP 18438 . 


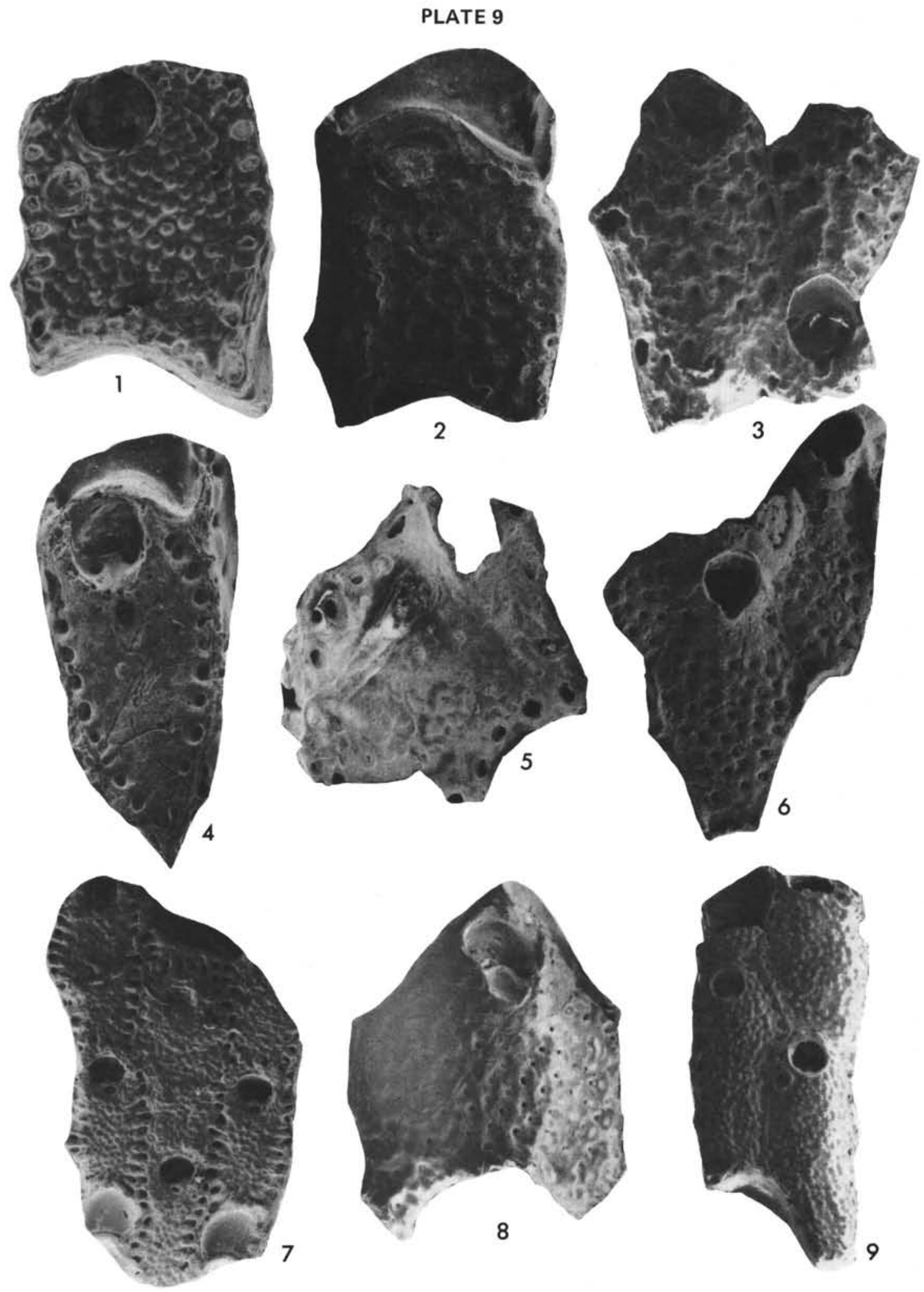

